JOURNAL OF

BUSINESS

UNIVERSIDAD DEL PACÍFICO

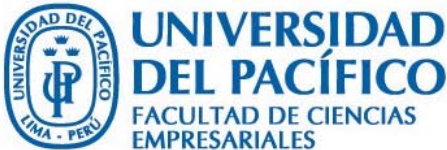

FACULTAD DE CIENCIAS

EMPRESARIALES

\title{
Factors that Contribute to Corporate Volunteering: Articulating Theory with the Practice of Companies
}




\begin{abstract}
Corporate Volunteering (CV) has grown in recent years, looming largely on the agenda of many companies and Civil Society Organizations (CSOs) both internationally and in Uruguay. The objective of this article is to identify the organizational factors that contribute to the management and development of $\mathrm{CV}$ and to analyze the articulation between, on the one hand, the theory underpinning the guides published by organizations that promote $\mathrm{CV}$, and on the other, the practices of Uruguayan companies, in order to determine the relevance of the latter as inspiring models of good practice for other companies. To this end, on the one hand, an exhaustive review of CV and CSR guides from Europe and America was carried out, and then a sample of ten guides was selected for thus study; and on the other, a comparative analysis was carried out of four case studies of Uruguay-based companies: Pronto!, Carle \& Andrioli, Telefónica, and Sabre. The methodological design entailed a mixed approach for the analysis of the companies and exploration of secondary information sources, with documentary analysis for the CV guides dimension. Among the main organizational factors identified are: the development of strategic $\mathrm{CV}$, the support of leadership and management, $\mathrm{CV}$ integrating and promoting the organizational culture of the company, the promotion of volunteer participation, adequate implementation of internal and external communication, inclusion of other stakeholders, and synergy between CV and CSR.
\end{abstract}

\title{
Resumen
}

El Voluntariado Corporativo (VC) ha crecido en los últimos años, apareciendo en gran parte en la agenda de muchas empresas y Organizaciones de la Sociedad Civil (OSC) tanto a nivel internacional como en Uruguay. El objetivo de este artículo es identificar los factores organizacionales que contribuyen a la gestión y el desarrollo del VC y analizar la articulación entre, por un lado, la teoría respaldando las guías publicadas por las organizaciones que promueven el VC; y por otro, las prácticas de las empresas uruguayas, para determinar la relevancia de estas últimas como modelos inspiradores de buenas prácticas para otras empresas. Para ello, por un lado, se realizó una revisión exhaustiva de las guías de VC y RSE de Europa y América, y luego se seleccionó una muestra de diez guías para el estudio; y por otro, se realizó un análisis comparativo de cuatro casos de estudio de empresas ubicadas en Uruguay: Pronto!, Carle \& Andrioli, Telefónica y Sabre. El diseño metodológico implicó un enfoque mixto para el análisis de las empresas y exploración de fuentes de información secundarias, con análisis documental para la dimensión de guías de VC. Entre los principales factores organizacionales identificados están: El desarrollo de VC estratégico, el apoyo de liderazgo y gestión, el VC integrando y promoviendo la cultura organizacional de la empresa, el fomento de la participación de voluntariado, la implementación adecuada de la comunicación interna y externa, la inclusión de otros grupos de interés, y la sinergia entre VC y RSE.

\section{Keywords:}

Corporate volunteering, corporate social responsibility, organizational culture, strategic alliances. 


\section{Introduction}

Corporate volunteering (hereafter, $\mathrm{CV}$ ) is a relatively new yet expanding topic on the agenda of many companies and civil society organizations (CSOs) in Uruguay and internationally. The practice of $\mathrm{CV}$, which introduces the unpaid volunteer to the profitdriven corporate sphere, implies the reconciliation of opposing rationales. This represents a substantial change to the mental model of value creation and income generation. CV refers to activities that are promoted and facilitated by enterprises whereby employees and retired employees offer their time and skills to the community entirely free of charge, as part of specific projects or programs (Lemonche, 2011)

The field has undergone global growth in recent years, as demonstrated by the growing academic and non-academic literature focusing on Europe, Asia, Oceania, and the Americas. CV was introduced to Uruguay in the late-1990s, buoyed by the consolidation of corporate social responsibility (CSR), the implementation of global CV programs at multinationals operating in Uruguay, and the establishment of various foreign CSOs and foundations that have a strong culture of partnership with the corporate sector, particularly when it comes to volunteering (Licandro \& Yapor, 2019).

Since 2011, the European Year of Volunteering, CV has been subject to considerable knowledge creation and dissemination (Sanz, et al., 2012). The systematized publications on $\mathrm{CV}$ include guides by organizations that promote the practice alongside CSR, such as those by Acción Empresarial (2008) in Chile; Fundación Compromiso (2008) in Argentina; CEMEFI (n/d) in Mexico; Observatorio de Voluntariado Corporativo (2009) and Fundación Telefónica (2012) across Latin America; Forética (2013), Instituto de Innovación Social ESADE, (2012) and Voluntare (2013) in Spain; Fundación ANDI (2016) in Colombia; and Fundación CODESPA (2012) in several countries in the Americas, Asia, and Africa, among other guides presenting definitions of $\mathrm{CV}$, associated activities, basic steps for implementation, factors related to management and development, case studies, and so on.

However, in the academic world, the literature is still incipient: "Employee Volunteer Programs also seem to be growing in importance, but empirical research on these is scant. [...] There seems to be an unfortunate gap between literatures in academic journals, professional journals, and various research institutions dedicated to studying corporate philanthropy" (Vaidyanathan, 2008: 2 and 37). Although in recent years there has been an increase in empirical research on $\mathrm{CV}$, there is still a need to increase academic output, and to improve communication and collaboration between the theoretical and practical approaches, as Vaidyanathan (2008) has noted.

The aim of the present article is to identify the organizational factors that contribute to the management and development of $\mathrm{CV}$, and to analyze the connection between the theory contained in the guides produced by organizations that promote volunteering, and the practices of Uruguayan companies. To this end, the present study involved an exhaustive search for CV and CSR guides in Europe and the Americas, and the subsequent selection of ten to focus on here. Then, a comparative analysis was conducted of four Uruguayan firms: PRONTO!, CARLE \& ANDRIOLI, TELEFÓNICA, and Sabre. The selected case studies were published in the journal Cuadernos de RSO, as 
part of research into CV carried out by the CSR Research Program at the Universidad Católica del Uruguay. The research involved identification of the organizational factors that contribute to $\mathrm{CV}$ development and management, and analysis of the degree of articulation between theory and practice in order to determine the relevance of CV as a model that inspires good practice among businesses. The methodological design utilized a mixed approach. For the case studies of the selected companies, semi-structured interviews were applied to employees in charge of CV and to volunteers, while surveys were applied to the former. In turn, an exhaustive descriptive review of ten CV guides from Europe and the Americas was conducted, and then correlations were established with the case studies.

The study enabled the identification of a common core of organizational factors in the CV guides, and a strong presence of these factors across the companies analyzed. These include: considerable synergy between CV and CSR, development of strategic $\mathrm{CV}$, design of programs aligned with the organizational culture, employee training, and internal and external communication, among others. Moreover, the application of these factors across the companies studied means that they can be held up as inspiring models of good practices for other enterprises.

\section{Theoretical Framework}

\section{What is meant by corporate volunteering?}

$\mathrm{CV}$ is a specific form of volunteering in which the private sector is the main protagonist. There are a range of definitions of the concept. For example, the Points of Light Foundation understands it as "any formal or organized means a company uses to encourage and support its employees to volunteer their time and skills in the service of their communities" (Points of Light, 1996:1). For the Compromiso Foundation in Argentina, it is a "set of activities promoted and facilitated by a company with the aim of creating and sustaining (by providing economic, human, and technological recourses) a participation channel for employees to give their time, skills, and talents to different social organizations" (Fundación Compromiso, 2008:5). Across the various definitions of CV, there is a general consensus that the activity is promoted by companies, that employees cannot be compelled to participate (Observatorio de Voluntariado Corporativo, 2009), and that the primary motivation is solidarity (Moreno, 2013).

\section{$C V$ in the framework of CSR and its benefits}

CV developed in a framework of corporate social responsibility implies that the associated programs and actions represent a win-win for all concerned: the community, the company, and the employees who take part as volunteers. Thus, one of the first steps is to establish and articulate needs and interests in order to find common ground on which to work and set goals. CV can be conceived as a type of CSR action oriented toward staff, whereby the company provides a space in which to express and channel solidarity, and to contribute to those in need. At the same time, it is also a CSR practice 
oriented toward external stakeholders (Licandro, 2016), such as the beneficiary community.

Indeed, the community can benefit from CV practices through access to large numbers of volunteers (some of them specialized) and company resources of different types (not just material), while social organizations can strengthen their image by working alongside the company that disseminates their social cause (Acción Empresarial, 2004). The effects on companies can be classified as "internal" or "external." Internals effect include development of teamwork and leadership skills, improvement of organizational culture, increased sense of belonging to the company, talent attraction and retention, and so on. In turn, beyond the company, CV practices can help to enhance the institutional image and strengthen the connection with stakeholders such as the local community, suppliers, and distributors (DERES, 2008).

Moreover, these activities give volunteers the opportunity to channel their desire to help others (something that might otherwise be difficult due to lack of time or know-how), develop skills (contact with situations and environments outside the workplace can bolster skills related to communication, teamwork, leadership, and empathy), generate social capital (by forging links with SCOs, distributors, and other actors), and foster solidarity.

\section{Factors that promote VC development}

According to the Guía de Voluntariado Corporativo Voluntare (Voluntare, 2013), CV is a practice that, managed correctly (that is, established, implemented, and monitored), adds value to society, companies, and employees in a responsible manner. Though there is no single or optimal way of designing or implementing a CV program given that management and volunteer mobilization techniques vary according to the company, its sphere of action, and its culture (Sanz et al., 2012), firms ought to have some basic conditions in place to ensure credibility, legitimacy, and acceptance among workers (Voluntare, 2013).

When it comes to these conditions, the guides consulted highlight the importance of familiarity with the profile of employees (beyond demographic characteristics such as age, education, and sex, and so on) in terms of social concerns, time restrictions due to other responsibilities, and beliefs and values, in order to cater opportunities accordingly (Sanz et al., 2012; Voluntare, 2013; etc.). In addition, the motivations and goals of everyone involved in CV-the company, the CSO, and the ultimate beneficiaries-must be taken into account.

The adaption of internal communications according to the characteristics of the different company areas and the choice of partner CSO (based on the compatibility of its philosophy and values, what it does, and whether it inspires confidence in the volunteers) is another factor that ought to be taken into account when encouraging employees to take part in CV (Sanz et al., 2012; Voluntare, 2013).

But besides boosting employee participation, some of the guides point to three requirements that are "indispensable" for CV programs to function: "They must be present for a company to lay the foundations for the smooth operation of a volunteer 
program" (Voluntare, 2013: 13 and 14). These requirements are (Sanz et al., 2012 and Voluntare, 2013): a working environment that promotes employee participation, the management's commitment to $\mathrm{CV}$, and the design and implementation of $\mathrm{CV}$ programs based on the culture of the company. These factors will be explored further in the analysis of the selected guides.

Academic research into CV has focused primarily on aspects related to the motivation and satisfaction of company volunteers (Costa de Azevedo, 2007; Dávila de León, 2010; De Gilder, Schuyt, and Breedijk, 2005; among others), as well as the reasons why companies decide to get involved in CV practices and the types of CV they engage in (Cavallaro, 2006). But the literature has paid less attention to the aforementioned factors the guides consider indispensable for involving employees and developing CV practices.

\section{Methodological Design}

The methodological design incorporates two dimensions: the companies and the CV guides. For the companies dimension, a case study methodology was used, with a mixed data-collection approach. This entailed semi-structured interviews and surveys applied to individuals in charge of $\mathrm{CV}$, semi-structured interviews with employees, and analysis of internal company documents detailing their mission, vision, and values. The design was applied in a standardized manner across the participating companies. As noted earlier, the four Uruguay-based companies selected were: Sabre, Pronto!, Carle \& Andrioli, and Telefónica. For the CV guides dimension, ten guides from Europe and the Americas were chosen, and then correlations were established with the case studies. In turn, the guides were selected based on the involvement that the organizations responsible have in promoting $\mathrm{CV}$, their connections to the companies that engage in these practices, their experience and track record, and the free availability of their guides. They are as follows: Fundación Codespa (2012), Fundación Compromiso (2008), Sanz et al. (2012), Acción RSE (2004), Voluntare (2013), Lemonche (2011), Fundación Andi (2016), Cátedra "la Caixa" (2013), Fundación Seres (2011), Fundación Telefónica (2012).

\section{The companies}

The four Uruguayan companies selected have different characteristics in terms of size and sector. Two of them are multinationals (Telefónica and Sabre) and two are Uruguayan-owned (Pronto! and Carle \& Andrioli), and each has operated on the market for a different length of time. But despite these differences, there are appreciable similarities in terms of how they manage $\mathrm{CV}$, and this too was central to their selection. The common denominator was the presence of factors essential to the sound implementation and development of $\mathrm{CV}$ programs. Moreover, the companies were selected based on the identification, in each case, of inspiring practices, in the sense intended by US corporate volunteering expert Kenn Allen: "those things that capture our attention and our imagination, that make us stop and think and can lead us to adopt or adapt them." (Allen, 2012: 11).

Thus, the intention is to describe a set of practices identified from these experiences that 
serve as a source of inspiration for other companies or stakeholders who are, or wish to be, involved in CV.

Next, a brief outline is provided of each company.

SABRE is a leading global supplier of technological solutions for the travel industry. Its technology and data-based products are used by airlines, hotels, and travel agencies to expand their business and transform the traveler's experience. The company operates in sixty countries and employs 10 thousand people. It has had a presence in Uruguay since 2004, where it has a workforce of around 900 people. Since its foundation, community volunteering has been at the heart of the company's CSR, and is promoted by the company headquarters. In Uruguay, Sabre has managed to adapt its volunteering programs to local circumstances, complementing community needs with employee initiatives. Drawing on Licandro's (2013) classification of CV, Sabre engages in 1) management volunteering activities (participation on the governing boards of institutions such as Deres, Desem, Fullbright, and Endeavor); 2) structured volunteering programs alongside local non-profit organizations that work for the health rehabilitation of children and young people (Teletón, Peluffo Giguens); and 3) ad hoc activities through the provision of volunteering programs specific to the country in which it operates.

TELEFÓNICA is a transnational integrated telecommunications provider (fixed ands mobile telephony, internet, television, fiber optics) offering communication, entertainment, and information products. It has several brands around the world, including Movistar (present in Uruguay), O2, and Vivo. Founded in Spain in 1924, the company currently has a presence in 21 countries, with around 113,000 employees. It has operated in Uruguay since 2005, and employs some 600 people in the country. The corporation's CV program was created by Fundación Telefónica Argentina in 2000 to meet demand among employees, who had stated their desire to help others and take part in charitable actions. The program was introduced in Uruguay that same year. Different activities were gradually introduced-some of them international (International Telefónica Volunteer Day, International Solidarity Vacations, Online Volunteering), and others based on the circumstances and needs in each country. Fundación Telefónica oversees the corporate volunteer network of Grupo Telefónica, and seeks to promote employee participation in social actions for the benefit of the community and the most disadvantaged.

PRONTO! defines itself as a technology company oriented toward the finance business. The company was initially founded as Pronto Crédito in 1997, and expanded to Montevideo in 2003. Today, Pronto! has 36 branches and 560 points of sale throughout the nineteen departments of Uruguay, in addition to a customer service center and a payment center. It has more than 650 employees. Through the application and development of advanced technology to process large volumes of information, it proposes "to promote social inclusion by acting as a gateway to loans for a segment of the population that has difficulty accessing the financial system" (Pronto!, 2016:12). The company's CV program was formalized in 2010, and its first steps were supported by a 
CSR committee acting on advisory from the DERES ${ }^{1}$ corporate network. At first, the activities were proposed by employees. After consolidating the knowledge it acquired through DERES and organizing itself in a more strategic manner, Pronto! opted to work alongside established social organizations that are active in the field of education and serve vulnerable children; these included Aldeas Infantiles, DESEM Foundation-Young Entrepreneurs, Fundación Niños con Alas, UNICEF, and Telethon.

CARLE \& ANDRIOLI: Carle \& Andrioli is a Uruguayan SME that provides tax, accounting, and auditing advice. It was founded in 1991. The implementation of CV at Carle \& Andrioli was not planned in advance as a strategy, but evolved out of CSR practices, consultation of the literature on the topic, and membership of organizations that promote it such as DERES and ACDE. ${ }^{2}$ Initially, the idea of CV emerged from the company director's earlier employment experience at a firm that had a subsidized canteen, soccer team, doctor, and dentist. Then, in 2002, when the director read material related to $\mathrm{CV}$, he was persuaded to initiate CSR actions in the local community. The company's first volunteering initiative involved construction at Techo $^{3}$ more than fifteen years ago. That enthusiasm for CSR and CV was later transmitted to the other team members, and the principles have been applied there ever since.

\section{Corporate volunteering guides}

CV guides or manuals are prepared by different organizations and aimed at volunteers themselves, the employees in charge of developing CV programs at companies, social organizations, and all other individuals and organizations that have developed, or are looking to develop, a volunteer program in the framework of CSR. The guides are theoretical and methodological, presenting a synthesis of the learning by companies and social organizations that have taken part in CV programs. Next, a brief overview is presented of the organizations whose guides were selected for this study.

Fundación Codespa is a Spanish development cooperation NGO established more than thirty years ago to promote the integral development of vulnerable individuals. Its mission is based on value and respect for human dignity, and trust in the ability to overcome adversity. The countries where it develops projects, with economic aid from Catalonia, are: Morocco, Angola, DR Congo, Colombia, Ecuador, Philippines, Dominican Republic, and Guatemala. Its CV guide is intended as a strategic multitool for the application of CV within organizations, aimed primarily at HR management and with an emphasis on inclusion as part of business strategy.

Fundación Compromiso is an organization oriented toward promoting the development of CSR projects, sustainability, and strategic investments with high social, environmental, and cultural impact through link-up with companies, public agencies, and social organizations (Fundación Compromiso, 2008). Its CV guide promotes the

\footnotetext{
${ }^{1}$ DERES is a non-profit organization that unites the major Uruguayan companies seeking to develop corporate social responsibility, from a conceptual standpoint and in terms of practical application.
}

2 The Asociación Cristiana de Dirigentes de Empresas (ACDE) is a non-profit association that offers its members a support network through which to face the challenges of the business world.

3 Techo is a CSO active in nineteen Latin American countries that aims to tackle the extreme poverty experienced by millions of slum dwellers through joint action between inhabitants and young volunteers. 
development of a strategic CV program as a basis for the priorities of companies, the needs of communities, and the skills and interests of volunteers in which the benefits for all concerned are identified through the "virtuous circle" approach. From this perspective, the guide provides technical and strategic support for $\mathrm{CV}$ and establishes the importance of creating a framework of social partnerships.

Fundación Sociedad y Empresa Responsable (SERES), is a Spanish non-for-profit organization founded in 2009 and wholly funded by private capital. It seeks to assist companies in creating value and assuming their role as a key agent in the resolution of social problems. The foundation focuses on social innovation, identifying trends and contributing to the connection between the private sector and society through the sustainable growth of both. Its CV guide (SERES, 2011) stresses the formulation of volunteering plans adapted to the characteristics of the organization and aligned with its strategies. One of the guide's main strengths is its "organizational impact map," which makes it possible to determine the intensity of the impact that CV programs have on the human resources and management of an organization.

"La Caixa" Department of CSR and Corporate Governance at the Universidad de Navarra Business School (IESE) was created in 2005 to promote and divulge innovative knowledge about CSR. Its lines of research are geared toward identifying and understanding the role of companies in society, the presence of CSR in company governance, and the dissemination of CSR to society. The department's CV guide establishes a CV development plan based on the " $5 \mathrm{C}$ theory" based on the fundamental dimensions of clarity, coherence, communication, credibility, and confidence.

Fundación Telefónica is the organization through which the Telefónica company channels its CSR activities. The foundation's CV program is one of the largest of its kind in the world, with more than 51,000 active participants reaching over 590,000 beneficiaries in the 27 countries where Telefónica has a presence. The overriding objective is to develop a solidarity network made up of employees of the Telefónica Group, who contribute knowledge, time, and enthusiasm to improve the quality of life and well-being of the communities where they operate (Fundación Telefónica, 2020). Its CV guide, published as "The Big Tent" (Allen, 2012), is geared toward companies worldwide, based on the concept of "inspiring practices."

Fundación de la Asociación Nacional de Empresarios de Colombia (ANDI) seeks to lead actions and projects aimed at building a more equitable society, providing theoretical and practical tools to support affiliated companies in making increasingly sustainable and impactful social investments. Its guide, "Transformative Corporate Volunteering," is intended to serve as an input that "awakens the spirit of service through Corporate Volunteering" (ANDI, 2016: 6).

Instituto de Innovación Social is part of the Escuela Superior de Administración y Dirección de Empresas (ESADE) in Spain. The institute is dedicated to academic research that promotes social transformation as a means of making a positive impact. Its guide features a section on the definition, forms, and origins of CV in the Spanish context. It also analyzes cases of Spain-based companies based on common variables, proposing success factors and recommendations for consolidating results-oriented $\mathrm{CV}$ and achieving a social impact. 
Forética is a leading Spanish association of companies and CSR professionals whose mission is to foster a culture of ethical management and social responsibility. Responsible for the implementation in Spain of the European Employee Volunteering Awards, the association seeks to disseminate good practices and knowledge, and to assist its member companies in designing, managing, monitoring, and assessing their programs. Forética's guide, "Voluntariado Corporativo. Un Puente de Colaboración Entre la Empresa y la Sociedad," considers CV as the "maximum expression of the contribution of private enterprise to society" (Lemonche, 2011:8); it sets itself up as a tool for action for the community, volunteers, and the company itself, thus improving the working environment, productivity, sustainability, and other factors that influence business success.

Acción Empresarial is a non-profit organization that emerged out of the Chilean business sector to promote CSR among companies that operate in that country. Its CV guide, "Voluntariado Corporativo: Guía Práctica Para Empresas," was devised to promote an increase in social action through $\mathrm{CV}$ within the business sector, demonstrating at the same time that such initiatives create value for a company (Acción Empresarial, 2004 ).

Voluntare in an international network that promotes CV in Europe and Latin America. It offers a meeting and collaboration space in which organizations, companies, and individuals can generate tools and services that promote quality and innovation in CV. The objective of the "Guía de Voluntariado Corporativo Voluntare" is to present possible internal challenges and barriers associated with the involvement of employees in $\mathrm{CV}$ activities, as well as success stories and improvement opportunities that have arisen from working groups in different countries (Voluntare, 2011).

\section{Factors in CV provision according to the CV guides:}

This section presents and describes the factors that were identified through analysis of the selected CV guides. It is worth clarifying that although almost all the factors are present in each of the guides, quotes from only a few are presented by way of example. In so doing, an attempt is made at representativeness.

- Synergy between CV and CSR: CV is presented in all the guides as a tool within corporate CSR strategies. "Insofar as companies choose to invest their efforts beyond the traditional donation of resources, corporate volunteering is validated as an important part of the companies' social investment programs" (Sanz et al., 2012:12). If CV programs are aligned with CSR, and if these programs are allowed to serve as a space for innovation that contributes to various social causes, then $\mathrm{CV}$ becomes an opportunity to learn first-hand about the social needs of stakeholders (potential customers, suppliers, local communities, and so on). This makes it possible to identify lines of action through which to foster social contribution, inclusive business, and responsible supply chains by increasing the opportunities for sustainability, integration with companies, and long-term impact (Voluntare, 2013). In this vein, the guides encompass the perspective of value generation by companies, the main social and economic actors of the 21st century. CSR is understood as an instrument for development $(C S R+D)$, and a driver of strategic businesses marked by greater 
Yapor, S. and Correa, P. (2020) Factors that Contribute to Corporate Volunteering: Articulating Theory with the Practice of Companies, Vol.12(1): 22-

inclusion, less poverty, and more-sustainable growth. This gives rise to the notion of $\mathrm{CV}$ for development $(\mathrm{CV}+\mathrm{D})$, considered as professional and technical, developed within an international dimension in which enterprises manifest their commitment to the fight against poverty" (Codespa, 2012).

- Strategic CV development: This is a common factor across the selected guides. It is considered necessary to promote a space for synergy between the interests and needs of the companies (their aims with regard to CSR and HR policies, and so on); the skills, interests, and expectation of the volunteers; and the needs and priorities of CSOs in order to identify and pursue common ends: "The most successful corporate volunteer programs are those that are built on the basis of integrating the priorities of the company, the interests of the employees, and the needs of the community" (Acción RSE, 2004:10).

A strategic CV model will seek to create social value for these three stakeholders through win-win relationships. In turn, there are multiple ways in which a company can direct its VC programs. In general terms, this means developing strategic projects involving a high level of commitment in the medium and long term, rather than specific initiatives. Under more strategic forms of collaboration, non-profit organizations are no longer seen by companies only as recipients of donations (monetary and in kind, related primarily to aid), but also as agents alongside which to promote initiatives that revolve around a mutual interest, with a view to generating social value based on the principles of strategic alliance and joint responsibility.

This presupposes a greater degree of proactivity and involvement by companies in CV promotion and management, integration of $\mathrm{CV}$ initiatives with the core business, institutional inclusion of CV programs in the CSR and/or HR policy and strategy, and complementarity with other initiatives that a company promotes for the benefit of CSOs.

A company's selection of "partners" with which to engage in CV is important in terms of shared interests, needs and values, given the importance to success of sustaining longterm strategic relationships founded on mutual trust.

In recent years, there has been a trend toward developing business strategies aimed at building social innovation strategies. Thus, CV+D is a useful tool for creating and managing inclusive business strategies (Fundación Codespa, 2012).

- Designing the CV program in line with company characteristics and culture: There are various factors that determine which type of CV program is best. Considerations such as the prominence of a company's current CSR policy, the type of corporate culture, the motivations of the workforce, and others must be taken into account when choosing a CV model aligned with the organizational values and characteristics "Corporate volunteering is part of company culture, and as such we aim at offering all its employees the opportunity to get involved (Allen, 2012:8). "Participation in CV is a matter of culture. If it is not part of the vision and strategy of a company, even if this is a large and profitable organization, it will not become part of CV for development [...] The workforce will only receive true commitment if the company culture encourages and exemplifies [CV]" (Voluntare, 2013: 118 and 101). Volunteering 
Yapor, S. and Correa, P. (2020) Factors that Contribute to Corporate Volunteering: Articulating Theory with the Practice of Companies, Vol.12(1): 22-

activities are supported by corresponding philosophies, expectations, and processes, ranging from philanthropic models of community assistance to strategic models aimed at generating social value through solutions that benefit the three parties involved in the process: the company, the volunteers, and the CSO.

- Promoting employee participation as volunteers: This factor is linked to the degree of employee involvement in the design and implementation of volunteer programs and initiatives (such as the choice of activities and/or partner CSOs), the expected time commitment (during employees' leisure time, time-off granted by the company, or a combination of both) and the company's openness to receiving proposals from employees related to performing or improve these initiatives. Employee volunteers are expected to contribute their specialized and professional knowledge. Thus, the CV activities carried out should be adapted to the employee profile.

It is important to create programs in which employees can deploy their professional knowledge and experience in an effective manner; that is, as far as possible, volunteering should be skills-based. Companies need to foster conditions that are conducive to volunteer activities, such as scheduling activities during business hours, including employees' families in CV activities outside business hours, and so forth. To maximize employee participation in $\mathrm{CV}$, a positive working environment is vital. Encouraging employees to get involved is also important insofar as they serve as a source of social innovation; that is, employees are often well placed to detect communities with social needs that the company can effectively address (Cátedra "la Caixa" , 2013).

To ensure that employees do take part, trust must be generated through the explicit commitment or the active and visible participation of company management. On the other hand, if employees feel that their jobs are in danger (due to economic crisis, restructuring projects, or any other factor that affects company operations or shakes employee confidence in the workplace), their participation in CV initiatives will be limited (Voluntare, 2013).

- Senior management commitment to the CV program: Management conviction and backing with regard to $\mathrm{CV}$ is an important means of gaining staff loyalty and, in turn, strengthening the company and its responsibility to society. "Only in this way will it be possible to create a strong business culture that incorporates CV into the company values" (Sanz, et al., 2012:111). Managers inspire confidence through an explicit commitment made visible by participating themselves as volunteers; directly inviting employees to take part in programs; expressing opinions about the value of volunteering; sending letters of thanks to volunteers; and holding events to recognize volunteers, with due allocation of resources (in terms of personnel, infrastructure, equipment, logistics, infrastructure structure, volunteer hours, and so on). Likewise, the commitment of middle managers is also essential. Thus, according to Telefónica CEO César Alierta Izuel "a corporate volunteering program in order to be successful must receive the support of management at executive level. [...] This outspoken commitment has a domino effect on all levels within the company and is an illustration of how the programme is deeply rooted in Telefónica corporate culture" (Allen, 2012:VIII). 
- Monitoring and assessment: The monitoring and measurement of indicators is a vital part of determining CV goal attainment. This involves assessing everything concerned: employee satisfaction, the CSO, the social value contributed, the benefits for the company (skills acquired by employees, improved working environment, improved productivity, and so forth). Just as important as these qualitative considerations are quantitative metrics regarding the number of employees participating, the value of the resources allocated, the results obtained, the medium- and long-term impacts, etc. The purpose of monitoring and assessment is clear: to stimulate discussion about the findings and identify improvement opportunities for all program stakeholders. The "Guía de Fundación Seres" (2011) proposes, for the assessment and oversight of CV programs, the design of an organizational impact map that graphically represents the various levels of impact: sectoral, strategic, and cultural, and so on. This allows companies to ascertain the influence of $\mathrm{CV}$ programs on critical capacities such as productivity, flexibility, and innovation.

- Internal and external communication of CV: When encouraging and motivating employees to participate, companies should use internal communication and dissemination that takes into account the emotional dimension of volunteering. As noted earlier, it is important that companies recognize and value the performance and achievements of volunteers through celebratory events, thank you letters, certificates of participation, and so forth. Externally, communication can inspire others to engage in such activities, while also strengthening the image of the company as being socially responsible. The development of communication in CV programs enables, among other things, a company's CSR area to manage the corporate image; moreover, "the task of raising awareness and disseminating the potential of the company as an agent of change is one of the most interesting possibilities of $\mathrm{CV}$ for development programs "(Fundación Codespa, 2012: 92).

- Defining the company area responsible for CV: "The implementation of a volunteer program demands the same level of seriousness and behavior adopted in any of the company's commercial projects" (Acción RSE, 2004:11). A working committee or a dedicated area of the company should be tasked with mapping the social actions carried out, identifying opportunities for voluntary action, and proposing an action plan that also takes into account the expectations of employees.

- Establishing criteria to support social projects: Companies should establish parameters that guide and underpin the decisions to support a certain project in preference to another, to ensure, for example, that the target population and social cause are aligned to the interests of the company and its main activity. This is related to the need to establish tangible, clear, and tangible targets for the CV program, and to ensure these are aligned to the business targets; the closer the alignment, the better the prospect of developing something sustainable (Fundación Codespa, 2012).

- Training of volunteers: When it comes to implementing a CV initiative, defining the associated activities, and identifying the specific issues to take into account with regard to the target population, among other considerations, there is a need to train, motivate, and support volunteers in their work with social organizations so as to promote the development of skills conducive to responsible participation. For this, there must be 
professional technical assistance (Fundación Compromiso, 2018). Both the company and the participating organizations play a fundamental role in volunteer training. It is vital that employees be guided in their role and attitude in working with vulnerable populations, in terms of reporting on the characteristics and culture of the communities with which they will work, clearly establishing the work targets through action plans for each volunteer, and managing expectations, context and skills development (Fundación Codespa, 2012).

- Networking: Networking involves establishing contact with other companies and CSOs to encourage reflection on $\mathrm{CV}$, exchange knowledge and experiences, and foster debate about common difficulties and challenges in order to contribute to the improvement of these practices. This can lead to strategic alliances that allow for activities that the company could not carry out on its own, or to a greater impact than would have been possible if the company had acted individually. Indeed, collaborative networks enable robust long-term relationships between the companies and the CSOs with which they work (Allen, 2012). Moreover, strategic partnerships or management can be established to achieve a complex goal or an ambitious outcome, pooling the assets of both partners in terms of technical support, management, financial resources (Fundación Compromiso, 2018).

Table 1 presents the factors in CV development identified through analysis of the selected guides, and notes whether each factor is present or absent in the respective guides. It can be noted that most of the factors feature largely in almost all guides, but that the extent to which they are developed depends on the stated objectives of each organization. 
Table 1. Factors in CV development according to CV guides

\begin{tabular}{|c|c|c|c|c|c|c|c|c|c|c|}
\hline & & & & Corp & rate vol & nteering g & & & & \\
\hline $\begin{array}{l}\text { Factors that } \\
\text { promote CV } \\
\text { development }\end{array}$ & $\begin{array}{c}\text { Sanz et } \\
\text { al., } \\
(2.012\end{array}$ & $\begin{array}{c}\text { Acción } \\
\text { Empresarial, } \\
\text { (2004) }\end{array}$ & $\begin{array}{l}\text { Voluntare } \\
\text { (2013) }\end{array}$ & $\begin{array}{l}\text { Lemonche } \\
\text { (2011) }\end{array}$ & $\begin{array}{l}\text { Fund. } \\
\text { ANDI } \\
\text { (2016) }\end{array}$ & $\begin{array}{l}\text { Fund. } \\
\text { Codespa } \\
\text { (2012) }\end{array}$ & $\begin{array}{c}\text { Fund. } \\
\text { Compromiso } \\
\text { (2008) }\end{array}$ & $\begin{array}{l}\text { Cátedra } \\
\text { "La } \\
\text { Caixa" } \\
\text { (2013) }\end{array}$ & $\begin{array}{l}\text { Fund. } \\
\text { Seres } \\
\text { (2011) }\end{array}$ & $\begin{array}{c}\text { Fund. } \\
\text { Telefónica } \\
\text { (2012) }\end{array}$ \\
\hline $\begin{array}{l}\text { Synergy } \\
\text { between CV } \\
\text { and CSR }\end{array}$ & $\mathrm{X}$ & $X$ & $X$ & $X$ & $X$ & $X$ & $X$ & $X$ & $X$ & $X$ \\
\hline $\begin{array}{l}\text { Strategic CV } \\
\text { development }\end{array}$ & $X$ & $X$ & $X$ & $X$ & $X$ & $X$ & $X$ & $X$ & $X$ & $X$ \\
\hline $\begin{array}{l}\text { CV } \\
\text { consistent } \\
\text { with } \\
\text { corporate } \\
\text { culture }\end{array}$ & $X$ & & $X$ & $X$ & & $X$ & $X$ & & $X$ & $X$ \\
\hline $\begin{array}{l}\text { Promoting } \\
\text { employee } \\
\text { participation } \\
\text { as volunteers }\end{array}$ & $X$ & $X$ & $X$ & $X$ & $X$ & $X$ & $X$ & $X$ & $X$ & $X$ \\
\hline $\begin{array}{l}\text { Support of } \\
\text { senior } \\
\text { management }\end{array}$ & $X$ & $X$ & $X$ & $X$ & $X$ & $X$ & $X$ & $X$ & & $X$ \\
\hline $\begin{array}{l}\mathrm{CV} \\
\text { monitoring } \\
\text { and } \\
\text { assessment }\end{array}$ & $X$ & $X$ & $X$ & $X$ & $X$ & $X$ & $X$ & $X$ & $X$ & $X$ \\
\hline $\begin{array}{l}\text { Internal and } \\
\text { external } \\
\text { communicatio } \\
\mathrm{n} \text { of CV }\end{array}$ & $X$ & $\mathrm{X}$ & $\mathrm{X}$ & $\mathrm{X}$ & $\mathrm{X}$ & $\mathrm{X}$ & $\mathrm{X}$ & $\mathrm{X}$ & & $X$ \\
\hline $\begin{array}{l}\text { Defining } \\
\text { company } \\
\text { area } \\
\text { responsible } \\
\text { far } \Gamma \mathbf{V}\end{array}$ & & $X$ & $X$ & $X$ & $\mathrm{X}$ & $X$ & $\mathrm{X}$ & & & $X$ \\
\hline $\begin{array}{l}\text { Establishing } \\
\text { criteria to } \\
\text { support } \\
\text { social } \\
\text { projects }\end{array}$ & $X$ & $\mathrm{X}$ & $X$ & $\mathrm{X}$ & $\mathrm{X}$ & $\mathrm{X}$ & $\mathrm{X}$ & $\mathrm{X}$ & $X$ & $X$ \\
\hline $\begin{array}{l}\text { Volunteer } \\
\text { training }\end{array}$ & $\mathrm{X}$ & $\mathrm{X}$ & $X$ & $X$ & $X$ & $X$ & $\mathrm{X}$ & $\mathrm{X}$ & $X$ & $X$ \\
\hline $\begin{array}{l}\text { Networkin } \\
\mathrm{g}\end{array}$ & & $X$ & $X$ & $X$ & & $X$ & $X$ & $X$ & & \\
\hline
\end{tabular}

Source: compiled by the authors. 


\section{Organizational factors that promote $\mathrm{CV}$ development in the companies analyzed}

Having analyzed the four case studies, it was found that each of the factors cited in the guides as being relevant to the design and implementation of $\mathrm{CV}$ are part of the practices of each company, in most cases to a significant extent. This allowed $\mathrm{CV}$ to become a sustainable practice around fifteen years ago, with a level of employee participation above 10\%, which the literature considers satisfactory (Acción Empresarial, 2004). The level of participation reaches $50 \%$ for certain activities, and as much as $90 \%$ in the case of Carle \& Andrioli.

Next, a summary is presented of how these factors are manifested in the CV practices of the companies analyzed.

1. Synergy between CV and CSR: CV is one of the tools that these companies use to channel their philosophy and their approach to CSR. In the four cases, CV has been developed in parallel with the formalization of CSR. At Sabre and Telefónica, CV constitutes one of the focuses of CSR, from the top down; in Uruguay, both firms have succeeded in adapting their volunteer programs to local circumstances, taking into account community needs and workers' initiatives. The emergence of CV policies at Sabre predates the establishment of CSR policies at headquarter-level; the company has employed such practices since its foundation, and the theoretical underpinnings came later. Similarly, and as noted earlier, the beginnings of CV at Pronto! and Carle \& Andrioli did not come as part of a definite strategy, but as an offshoot of the company's CSR practices, consultation of the literature (in the latter case), and involvement in Uruguayan organizations that promote it, such as DERES and ACDE. All companies distinguish between community CSR (outward-facing) and employee CSR (inwardfacing).

2. Strategic CV development: $\mathrm{CV}$ is promoted by these firms as an experience that makes a positive contribution to all actors involved: themselves as companies, their employees, and the community. They conceive of CV as being framed within a CSR approach that unites the perspective of employees (as human capital) with that of volunteers (as the basis of social actions). This approach is known as "overcoming" (Licandro, 2016), in that it overcomes the limitations of each individual approach; that is, social actions are not chosen solely on the basis of human capital development objectives, and nor are volunteers considered simply as means of bringing about social actions. The companies provide a space for expressing and channeling employee solidarity and, in turn, contributing to those in need. In all cases, CV practices are found to be in alignment to company policy. The two multinational companies (Sabre and Telefónica) possess global strategies aligned to the business vision and mission, though their offices in each country have the freedom to adapt that strategy to prevailing local conditions. This means that CV practices are tailor-made to the needs of the recipient communities, leading to more effective results. For Pronto!, social commitment is a "strategic driver" of which CV is part. And as far as Carle \& Andrioli is concerned, CV constitutes a set of tools that contribute to employees' personal and professional development, while also allowing the company to promote its values and contribute to the community. 
3. CV consistent with corporate culture: Sabre, Telefónica, Pronto!, and Carle \& Andrioli all design and implement $\mathrm{CV}$ in keeping with the characteristics of their corporate culture. This can be appreciated not only in the formal expressions of their business philosophy (mission, vision, codes of ethics, CSR reports, etc.), but also-according to employee testimonials-in their day-to-day operations. CV, just like CSR, is part of organizational culture, and this is one of the first characteristics to be conveyed to any new employees who join these companies. Thus, Sabre develops CV programs based on its pillars of driving positive environmental and social change and serving its communities alongside employees and customers. A distinguishing feature of this company is its innovation and encouragement of employees to develop creative and innovative capacity within CV.

Telefónica seeks to ensure that its CV is aligned with the spirit of the company, using technology to strengthen solidarity actions focused on the community. The firm's CV activities and objectives, as well as the professionalism with which these practices are overseen, reflect three values that govern its business decisions and practices: being reliable, challenging, and open. Meanwhile, Pronto! regards CV as part of its CSR philosophy and, when it comes to managing it, its organizational culture. Its core organizational values (integrity, desire to excel, and commitment) serve as criteria that guide CV activities, as well as the selection of volunteers and the CSOs with which the company works. For its part, Carle \& Andrioli looks upon CV as a way of harmonizing its values, mission, vision, and code of conduct, and of crystallizing them through actions that contribute to the community and to the personal and professional development of its employees. Employees understand $\mathrm{CV}$ as a characteristic that defines both the company and them as its staff members.

4. Promoting employee participation as volunteers: All four companies encourage employees to participate in CV by communicating their interests and proposals (through meetings, surveys, and other measures) with regard to activities and their implementation. This has a positive impact on volunteers' personal and professional development and on the working environment, fostering a sense of belonging to each company. Sabre's employees can get involved in the activities that the company organizes, and are free to start and join teams responsible for the various activities that they themselves propose. At Telefónica, the invitation to take part in CV is extended to retired and retiring employees as well as employees' friends and family in order to multiply the impact of the actions. Annually, as part of its CV program and in alignment with the foundation's strategy and sustainable development goals, Telefónica gives employees the opportunity to propose, design, and execute their own project, issuing an "appeal for solidarity ideas." Both Telefónica and Pronto! review the requests of those who want to volunteer according to the activities they wish to get involved in, based on, among other factors, their interest in participating, their behavior as employees, the skills required, and so on. At the later firm, volunteering is seen as a reward or a recognition of select employees. Carle \& Andrioli, as an SME, facilitates coordination to ensure that all employees to wish to volunteer can do so.

5. Commitment and support of senior management: The case studies show that senior and middle managers provide support and commitment through participation in CV activities. At Sabre, their participation goes beyond strategic planning and resource 
allocation, to include personal support during certain critical situations that local communities have faced, such as following the tornado that hit the city of Dolores in Uruguay. Moreover, at Pronto! and Carle \& Andrioli, senior and middle manager take part in volunteer activities while also incentivizing and encouraging participation among their subordinates.

Telefónica operates under the premise that executive-level support is a requirement for the success of a CV program. Through Fundación Telefónica, the company promotes the involvement of all employees, retired employees, and family-members, and senior managers play an active part. This approach, also taken across the other companies analyzed, encourages employee participation through leadership by example. The different types of resources that senior management apportions to CV also constitute forms of support and commitment. Examples of the different kinds of resources include: funds (donations, event sponsorship, etc.), intellectual capital (managers' attendance of events), social capital (fund-raising activities alongside customers, provision of access to the CSO for suppliers and other related companies), operational resources (goods, equipment, and tools donated, etc.), and, fundamentally, human capital (volunteer work by managers and employees, training, support, and mentoring activities, volunteering during business hours, etc.).

For example, Pronto! makes available its human capital by, for example, providing workshops on financial education and responsible consumption; gives SCOs access to the company's social capital; leverages funds as subsidies for the beneficiary individuals, among other applications; sponsors events; and holds awareness-raising campaigns about the work of its partner SCOs. In turn, Carle \& Andrioli, lends its intellectual capital in the form of free accounting advice for CSOs: allocates its social capital by involving its customers in CV activities, and utilizes its human capital by providing training, tutorials, and internships, and, of course, by allocating hours to volunteering (and to the associated planning and training).

6. CV monitoring and assessment: This factor was identified across all companies included in the study. The employees tasked with the assessment process are usually those in charge of the CSR activities; the process involved detailed monitoring of the activities in themselves, and of the results. For example, at Sabre assessment meetings follow completion of $\mathrm{CV}$ activities, and then the results are fed back to volunteers. This is important not only to measure the impact of $\mathrm{CV}$ activities on both the company and the community, but also to promote a sense of belonging and identity among the volunteers. CV activities are assessed through measurement of indicators that serve to steer the activities. The indicators utilized by Sabre include: human resources involved (number of volunteers, paid hours assigned to CV activities), financial and other resources contributed by the company, level of satisfaction among volunteers, level of satisfaction among beneficiary organizations, and attainment of targets relating to benefits for volunteers and the company. Moreover, at the time of the study, the company felt that there was much still to be done when it came to defining enough key performance indicators to be able to assess its CV program. Moreover, Telefónica, which has a monitoring and assessment system in place, acknowledges, in its CV guide, the importance of evaluating performance, results, and impact internationally, but also 
concedes that there is still not enough invested in measuring these activities, and that it is working to improve this.

7. Internal and eternal CV communication: This factor is a key instrument in promoting volunteering among employees. Each of the companies have internal and external dimensions to their communications. For internal communication, a plan will generally be created to accompany the entire $\mathrm{CV}$ process. A communication plan is implemented prior to the launch of activities to generate expectations and promote involvement among employees, and continues through the realization and result-sharing stages.

The companies utilize different channels of communication. For example, at Carle \& Andrioli and Sabre, communication is by email, the company website, and office monitors. According to those in charge of $\mathrm{CV}$ at the company, the biggest communication challenge lies in finding a balance so that: "Employees are kept informed of what is being done, but not saturated, as this could have the opposite effect of the employees losing interest in participating" (Correa, 2017). Meanwhile, social media platforms and the press play an important role in external communication, publicizing the activities that make up the CSR program. This communication is intended to create synergy with other companies by encouraging participation in the activities and sharing good practices. It is also aimed at attracting new talent, given that $\mathrm{CV}$ is increasingly valued when deciding which company to work for. Fundación Telefónica manages its communication through the Telefónica intranet, its web portal, and internal memos, but also through the induction process, meetings, training events and courses, and workshops.

8. Defining the company area responsible for CV: Each of the companies has an area in charge of CV. This was the outcome of a lesson learned; in most cases, volunteer efforts were initially on the initiative of volunteers, without a clear definition of responsibilities or structure. Thus, Sabre now oversees CV by way of a committee made up of managers from different areas, while Carle \& Andrioli's CSR committee, which channels staff initiatives related to CSR and CV practices, is open to the voluntary participation of employees of all levels and from all areas of the company. In Spain, Telefónica created Fundación Telefónica (known in Uruguay as Fundación TelefónicaMovistar) to oversee its community-facing CSR actions. CV is one of the foundation's strategic lines of actions, and it has an employee tasked with coordinating this initiative. In the case of Pronto!, the company's human capital and communication area contains a "communication and CSR" section that leads the CST program and devises CV proposals, which it shares with its overarching area. Moreover, the company has a CSR committee whose members reproduce the CSR philosophy throughout the different areas of the company, as well as providing logistical support for the activities undertaken.

9. Establishing criteria for the support of social projects: The four companies conduct different types of volunteer activities. Carle \& Andrioli and Sabre carry out management volunteering, whereby company managers sit on the boards of CSOs in order to contribute to their sustainable development. The companies also undertake ad hoc activities in response to emergency situations (by way of fund-raising campaigns, shelters, etc.), as well as participating in volunteer programs whereby employees volunteer for initiatives developed and organized by CSOs that have been tested, assessed, and improved. 
As noted earlier, the four companies started out implementing ad hoc volunteer actions, but gradually came to realize the advantages of taking part in structured volunteer programs. Another learning was the need for criteria to decide which CSOs and causes to support. Some of the most salient criteria are: that the organizational values of the CSOs be aligned with those of the company (such as respect, responsibility, transparency, and solidarity, among others); that the social cause be of interest to volunteers and aligned with those of the core business (such as holding workshops associated with the company's main activity, whether financial, accounting, or telecoms); and that the CSOs be run in a professional manner. This allows the companies to save time and energy to organize their activities, be less uncertain about the processes and their possible results (since these organizations and their procedures are well known and highly regarded), and select the programs that most closely match their aims.

10. Training of volunteers: All the companies understand that training is another key factor in the success of their CVF programs. Depending on the size of the organization, there are various possible strategies for training. For example, Telefónica has a global online platform for accessing different levels of training. The firm also operates a Volunteer School whose aim is to train volunteers in areas of interest, from basic familiarization with general aspects common to all activities, to grasping more-specific aspects associated with the different focuses of $\mathrm{CV}$, such as volunteering for children, persons with disabilities, populations in extreme poverty, etc. Telefónica also plans training for each activity in order to align all volunteers to a single starting point, designate roles, plan activities, and so on. Just as the CV guides propose, the companies understand the importance of volunteers understanding the culture of the community with which they will work, for which training plays a vital role.

11. Networking: The companies, as they consolidated their CSR and CV practices over time, gradually involved suppliers, customers, and partner CSOs in their initiatives. They have formed strategic working alliances with these and other organizations to design and implement solutions to concrete problems, pooling resources and achieving more impactful results. This reflects the level of commitment and coordination between the parties and the establishment of medium- and long-term agreements (such as CV activities as part of alliances stretching back more than ten years), rather than just the planning of specific instances of collaboration. Moreover, membership of organizations that promote CSR and CV practices nationally (such as DERES and ACDE) and, in some cases, internationally (such as the UN Global Compact) have been fundamental for the consolidation of $\mathrm{CV}$, the exchange of experiences, and the detection of improvement opportunities.

\section{Conclusions}

Thus study enabled, the identification of a series of organizational factors that contribute to the management and development of $\mathrm{CV}$, insofar as they are present in the $\mathrm{CV}$ guides and the four companies studied. These factors are related to: 1- synergy between CV and CSR; 2- development of strategic CV; 3- CV consistent with the business culture; 4encouraging employee participation as employees; 5- senior management commitment 
and support; 6- CV monitoring and assessment; 7- internal and external communication about CV; 8- deciding which area or department will oversee CV; 9- establishing criteria for the support of social projects; 10- volunteer training; and 11- networking.

IT was found that the organizational factors identified in the CV guides are present across all four companies studied, and, thus, that there is articulation between the theoretical underpinnings of the guides and the firms' practical implementation. But despite this evidence of articulation, and of the development of CV internationally, the practice must still be strengthened and made more effective through the integration of other factors of importance to their management. This recommendation is oriented to improving exchange and collaboration between all parties, and to building a collaborative network to promote $\mathrm{CV}$ development based on different knowledge and experiences.

A limitation identified in this study relates to the representativeness of the sample of companies and guides, given that the selection was intentional. Thus, to built upon this study, a broader sample should be selected for both dimensions.

Finally, CV practices at the companies analyzed can be taken as a benchmark of inspiring practices for other enterprises, given the longevity of their programs and their impacts and benefits for stakeholders. Although "there is no 'best way' to do Corporate Volunteering" (Allen, 2012:17), the results obtained in this article, in terms of the factors that enable the application and consolidation of CV practices, can serve as a useful input for those who wish to start designing and implementing $\mathrm{CV}$ or those who wish to contribute to its development and management.

\section{Bibliography}

Acción Empresarial (2004). Voluntariado Corporativo. Guía práctica para empresas. Santiago de Chile. Retrieved from: http://www.sumarse.org.pa/site/wpcontent/uploads/2012/03/GuiadeVoluntariadoCorporativo.pdf [2015, May 04]

Allen, K. (2012). The Big Tent: Corporate Volunteering in the Global Age. Fundación Telefónica. Barcelona: Editorial Ariel. Retrieved from: https://www.iave.org/iavewp/wpcontent/uploads/2015/04/The-Big-Tent-2012.pdf [2020, November 24]

Cavallaro, L. (2006). Corporate volunteering survey. The extent and nature of corporate volunteering programs in Australia. Australian Journal on Volunteering. 11(1), 65-69.

CEMEFI (n/d). Voluntariado en las empresas. McBride Sustainability, Give and Gain Day 2012.

Correa, P. (2017). "Sabre: gestión y experiencia del voluntariado corporativo en Uruguay" en Cuadernos de RSO. Publicación Interdisciplinaria sobre Responsabilidad Social de las Organizaciones, 5 - n¹ 2017 p.

103 - 125. Programa de Investigación sobre RSE. Universidad Católica del Uruguay. Montevideo, Uruguay: Mastergraf SRL.

Costa de Azevedo, D. (2007). Voluntariado Corporativo -Motivações para o trabalho voluntário. XXVII Ponencia presentada en Encontro Nacional de Engenharia de 
Yapor, S. and Correa, P. (2020) Factors that Contribute to Corporate Volunteering: Articulating Theory with the Practice of Companies, Vol.12(1): 2244

Produçao, October 09-11, 2007. Foz do Iguaçu: Unisinos. Retrieved from: http://producaoonline.org.br/rpo/article/view/55/55 [2015, 02 de junio]

Dávila de León, M. (2010). "Motivaciones personales en Voluntariado Corporativo" en Revista de Responsabilidad Social de la Empresa. ISSN 1888-9638, 3, 103-120

De Gilder, D., Schuyt T., and Breedijk M. (2005). Effects of an Employee Volunteering Program on the Work Force: The ABN-AMRO Case. Journal of Business Ethics. 61,143152.

DERES (2008). "El voluntariado genera un círculo virtuoso" in Revista de Responsabilidad Social Empresarial. 7, 46-47. Montevideo.

Fundación ANDI (2016). Guía de Voluntariado Corporativo Transformador. Banco de Desarrollo de América Latina y Asociación de Trabajo Voluntario.

Fundación Codespa (2012). Voluntariado Corporativo para el Desarrollo. Madrid, España: CODESPA.

Fundación Compromiso (2008). Manual de Voluntariado Corporativo. Buenos Aires, Argentina.

Fundación Telefónica. (2020). Retrieved from: https://www.fundaciontelefonica.com/voluntarios/ [2020, August 15]

Garralda J. (n/d). Diagnóstico para un voluntariado eficaz. Fundación SERES. Madrid, Spain.

González, A.M., Negueruela, M., Dávila, M.C. (2008). Voluntariado apoyado por la empresa: Guía para entidades de acción social. Madrid, Spain: Dirección General de Voluntariado y Promoción Social. Comunidad de Madrid.

Jané, R. (2010). Voluntariado Corporativo: elementos para su impulso. CIES. Universidad de Barcelona. Barcelona, España.

Lemonche, P. (2011). Voluntariado Corporativo. Un puente de colaboración entre la empresa y la sociedad. Madrid, Spain: Forética.

Lamont, O. (2016). Responsabilidad Social Empresaria. Reflexiones, investigaciones y Casos. Montevideo: Grupo Magro.

Licandro, O. \& Yapor, S. (2019). Los beneficios del Voluntariado Corporativo para la gestión de los Recursos Humanos. Paper presented at IV Congreso Uruguayo de Sociología: El oficio del Sociólogo/a en tiempos de cambio. Montevideo, Uruguay.

Moreno, V. (2013). El voluntariado desde la empresa. Cuadernos de la Cátedra "La Caixa" de Responsabilidad Social de la Empresa y Gobierno Corporativo. No 20. Observatorio de Voluntariado Corporativo (2009). Informe. Voluntariado Corporativo en España. Madrid: Observatorio de Voluntariado Corporativo.

Oxoby, A. (2016). "La gestión del voluntariado corporativo en Fundación Telefónica Movistar" Uruguay en Cuadernos de RSO. Publicación Interdisciplinaria sobre Responsabilidad Social de las Organizaciones, 4 - n² 2016 p. 93 - 113. Programa de Investigación sobre RSE. Universidad Católica del Uruguay. Montevideo, Uruguay: Mastergraf SRL. 
Points of Light Foundation (1996). "Developing a Corporate Volunteer Program Guidelines for Success."

Pronto! (2016). Memoria RSE 2015 de Pronto! Montevideo.

Sanz, B., Cordobés, M. and Calvet, A. (2012). El voluntariado corporativo en España. Modelos y perspectivas de impacto social. Instituto de Innovación Social. Barcelona: Universidad Ramón Llull.

Vaidyanathan, B. (2008). Corporate Giving: A literature review. Center for the Study of Religion and Society. University of Notre Dame.

Voluntare (2013). Guía de Voluntariado Corporativo Voluntare. Retrieved from: http://www.corresponsables.com/webfm send/216 [2015, June 02 ].

Yapor, S. (2016) "El Voluntariado Corporativo como herramienta de gestión de la cultura organizacional de RSE. El caso de Pronto!" in Cuadernos de RSO. Publicación Interdisciplinaria sobre Responsabilidad Social de las Organizaciones, v.: 41 , p.:77 100. Programa de Investigación sobre RSE. Universidad Católica del Uruguay. Montevideo, Uruguay: Mastergraf SRL.

Yapor, S. and Licandro, O. (2015). "La relación entre Responsabilidad Social Empresaria y Voluntariado Corporativo. El caso de Carle \& Andrioli" en Cuadernos de RSO. Publicación Interdisciplinaria sobre Responsabilidad Social de las Organizaciones. 1, 109-132. Programa de Investigación sobre RSE. Universidad Católica del Uruguay. Montevideo, Uruguay: Mastergraf SRL. 